\title{
EXPERIMENTALWORKS
}

UDC 577.151.042: 577.152.34 + 547.787.1

doi: https://doi.org/10.15407/ubj91.04.005

\section{1,3-OXAZOL-4-YLPHOSPHONIUM SALTS AS NEW NON-PEPTIDE INHIBITORS OF FURIN}

\author{
T. V. OSADCHUK ${ }^{1}$, V. K. KIBIREV $V^{1,2}$, O. V. SHYBYRYN ${ }^{1}$, A. V. SEMYROZ, \\ Ye. S. VELIHINA', E. R. ABDURAKHMANOVA ${ }^{1}$, V. S. BROVARETS ${ }^{1}$ \\ ${ }^{1}$ V.P. Kukhar Institute of Bioorganic Chemistry and Petrochemistry, \\ National Academy of Sciences of Ukraine, Kyiv; \\ e-mail: brovarets@bpci.kiev.ua; \\ ${ }^{2}$ Palladin Institute of Biochemistry, National Academy \\ of Sciences of Ukraine, Kyiv
}

Received: 22 February 2019; Accepted: 17 May 2019

\begin{abstract}
A series of novel triphenylphosphonium derivatives of 1,3-oxazole containing at C2 and C5-positions electron withdrawing or electron-donating groups were synthesized and characterized by ${ }^{1} \mathrm{H},{ }^{31} \mathrm{P} N \mathrm{NR}$ and IR spectroscopy, element analysis and chromato-mass spectrometry. These compounds were found to be a new class of non-peptide inhibitors of furin. Depending on the chemical structure, they inactivated enzyme at micromolar level by mechanism of competitive, non-competitive or mixed inhibition. Evaluation of the synthesized derivatives as furin inhibitors showed that among the triphenylphosphonium salts studied by us, oxazole 12 containing 2,4-dichlorophenyl- in the C2-position and MeS-group at C5 is the most active $\left(K_{i}=1.57 \mu M\right)$ competitive inhibitor of furin. Our results provided evidence that chemical modification of 1,3-oxazole-4-yltriphenylphosphonium salts may be useful for developing new more potent and selective inhibitors of furin.
\end{abstract}

Ke y w o rd s: furin, inhibitors, 1,3-oxazole derivatives, triphenylphosphonium salts, mechanism of inhibition.

$\mathrm{T}$ he enzyme furin (EC 3.4.21.75) is a multidomain, calcium-dependent serine proprotein convertase subtilisin/kexin type, which converts inactive precursors of proteins into mature biologically active products: hormones, growth factors, receptors, enzymes, adhesive molecules, ion channels, blood coagulation factors, etc. [1-3]. Furin is involved not only in normal physiological processes, but also in the development of a number of pathological conditions: infectious diseases, neoplastic formations, cardiovascular diseases, obesity, diabetes, neurological and cognitive dysfunctions, as well as impaired reproduction and bone mineralization [4-6]. Therefore, the enzyme is considered as a promising target for the synthesis of its inhibitors and the creation of modern drugs based on them [3-6]. The search for potential inhibitors of furin among low-molecular weight compounds of a nonpeptide nature is an important area of biochemical research, since such compounds exhibit increased metabolic and proteolytic stability [7, 8]. In addition, they are easily accessible by synthetic methods, and by structural modifications of these molecules it is easy to carry out a structure-activity relationship analysis. In recent years, different classes of compounds have been discovered that are capable of blocking the activity of proprotein convertases and, in particular, of furin [7-10].

Earlier, we have studied the inhibitory effect of some derivatives of thiazole and pyrazole and found that, under the experimental conditions, they inhibited the enzyme by $15-90 \%$ [11]. Continuing the search for new non-peptide inhibitors of furin, we paid attention to 1,3-oxazole derivatives. Zhang et

(C) 2019 Osadchuk T. V. et al. This is an open-access article distributed under the terms of the Creative Commons Attribution License, which permits unrestricted use, distribution, and reproduction in any medium, provided the original author and source are credited. 
al. note in a recent review [12], that oxazole compounds are readily able to bind with a variety of enzymes and receptors in biological systems via diverse non-covalent interactions, and thus display versatile biological activities [12]. These compounds are of particular interest, firstly, due to the presence of the oxazole moiety in various natural compounds [13], and, secondly, due to the fact that they are used as precursors in various chemical transformations $[14,15]$. Thus, the diverse oxazole-containing heterocycles are highly useful derivatives from synthetic and medicinal as well as pharmaceutical aspects. They were found to possess antibacterial, antifungal, anticancer, anti-inflammatory properties [14-16]. The heterocycle was shown to play a vital role in synthesis and manufacture of varies drugs as brainderived neurotrophic factor inducers [17], anticancer agents [18-21], antidepressants and anticonvulsants [22], compounds with antimicrobial, antiviral and antifungal activities [23-28], as well as antidiabetic [29] activity.

To create new bioregulators, chemists use usually diverse chemical modifications of the initial structures by various pharmacophoric groups. One of these groups is the lipophilic triphenyl-phosphonium (TPP) ion [30-32]. Indeed, the derivatives, bearing quaternary phosphonium salts were reported to show high antimicrobial activities [33-35] so that these cations were considered as a new generation of effective antiseptics. As pharmacological agents, TPP salts found to have also antiglycemic properties [36] and antiproliferative [36], antioxidant [37], antiviral activities [34]. It is important that the phosphonium cation itself does not exhibit cytotoxicity [38].

Since, furin recognizes in its natural substrates a portion of the polypeptide chain enriched in basic amino acid residues: -Arg-Xn-(Lys/Arg)-Arg- $\downarrow$, where $n=0,2,4,6$, and $\mathrm{X}$ is any amino acid except Cys [4], then positively charged substituents are introduced into the structure of furin inhibitors: a guanidine group or its mimetics, for example, amidine, amidinohydrazone, aminomethylbenzamidine and other groups [7-10].

The aim of the work is design, synthesis, and evaluation of some derivatives of 1,3-oxazol-4-yltriphenylphosphonium salts as new non-peptide furin inhibitors.

\section{Materials and Methods}

Reagents and preparations. The fluorogenic substrate Boc-Arg-Val-Arg-Arg-AMC was purchased from Bachem (Switzerland), and truncated recombinant human furin (2000 units/ml) was obtained from New England BioLabs (USA). Commercial furin solution was diluted 80-fold with HEPESbuffer ( $\mathrm{pH} 7.3$; $100 \mathrm{mM}$ HEPES, $1 \mathrm{mM} \mathrm{CaCl}_{2}, 0.5 \%$ Triton X-100 and $1 \mathrm{mM} \beta$-mercaptoethanol) and used then in the enzymatic reaction. One unit of furin activity was defined as quantity of the enzyme, that under standard conditions, cleaved off 1 picamol of 7-amino-4-methylcoumarin (AMC) in $1 \mathrm{~min}$.

EDTA, $\beta$-mercaptoethanol, HEPES, Triton X-100 were purchased from Sigma Aldrich.

General method for the synthesis of triphenylphosphonium derivatives of 1,3-oxazole. [2-R-4-(Triphenylphosphonium)-1,3-oxazol-5-yl] sulfanides 1-5 were synthesized according to the known method [39] from the starting N-(1,2,2,2tetrachloroethyl)amides $\mathbf{A}$. These compounds were converted into phosphonium chlorides $\mathbf{B}$ by reaction with triphenylphosphine running in benzene by heating to $70-80^{\circ} \mathrm{C}$. Interaction of phosphonium salts $\mathbf{B}$ with an excess of sodium hydrosulfide gave [2-R-4-(triphenylphosphonium)-1,3-oxazol-5-yl] sulfanides 1-5 (Scheme 1). Sequential interaction the compound $\mathbf{3}$ with 4-chlorodiazonium chloride and sodium perchlorate formed phosphonium salt 6, which has been converted to the corresponding sulfone 7. Alkylation of compounds 4, 5 with alkyl iodides leads to phosphonium salts $\mathbf{8}, \mathbf{1 2}$. Treatment of the compound $\mathbf{4}$ with phenacyl chloride and the subsequent with sodium perchlorate gives the phosphonium salt $\mathbf{9}$. The sequential processing of the compound $\mathbf{4}$ with chlorine and sodium perchlorate derives 5-chlorosubstituted oxazole $\mathbf{1 1}$.

2,2-Dichloro-1-(4-aroylamino)ethenyltriphenylphosphonium chlorides $\mathbf{B}$ were used to synthesize 5-N-substituted oxazoles 10, 13 (Scheme 2). The reactions were performed out at $20-25^{\circ} \mathrm{C}$ by mixing reagents $\mathbf{B}$ and hydrazine hydrate, or dimethylamine in methanol. The resulting (1,3-oxazol-4-yl)triphenylphosphonium chlorides were converted into the corresponding perchlorates 10, 13.

Chemistry: synthetic procedures and spectroscopic data of compounds. ${ }^{1} \mathrm{H},{ }^{31} \mathrm{P}$ NMR spectra were obtained on a Bruker AVANCE DRX-400 spectrometer (TMS as internal reference or $85 \%$ phosphoric acid as external reference) in DMSO- $\mathrm{d}_{6}$. IR spectra were recorded on a Vertex 70 spectrometer in $\mathrm{KBr}$ pellets. GC-MS spectra were recorded on an LC-MS system - HPLC Agilent 1100 Series equipped with a dinode array detector Agilent LC $\backslash$ MSD SL. Parameters of GC-MS analy- 
<smiles>[R]C(=O)NC(Cl)C(Cl)(Cl)Cl</smiles>

A
B<smiles>O=C(OCCl)c1oc(-c2ccccc2)nc1[18O]CCl</smiles>

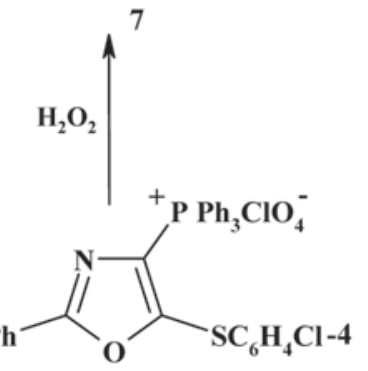

8,12

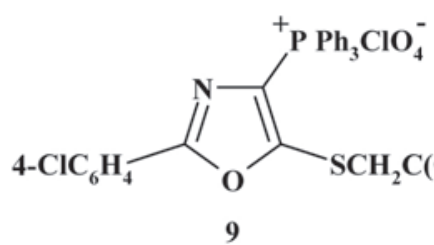

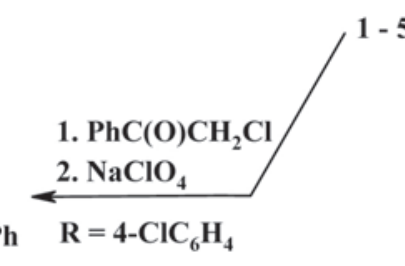
5

6 $\underset{\mathrm{R}=4-\mathrm{ClC}_{6} \mathrm{H}_{4}}{\stackrel{\text { 1. } \mathrm{Cl}_{2}}{2} \mathrm{NaClO}_{4}-\mathrm{ClC}_{6} \mathrm{H}_{4}}$ $\underset{\mathrm{R}=4-\mathrm{ClC}_{6} \mathrm{H}_{4}}{\stackrel{\text { 1. } \mathrm{Cl}_{2}}{\text { 2. } \mathrm{NaClO}_{4}}}$

11

Scheme 1. Synthesis of [2-R-4-(triphenylphosphonium)-1,3-oxazol-5-yl]-sulfanides (1-5) and (1,3-oxazol4-yl)-triphenylphosphonium salts $(6-9,11,12)$

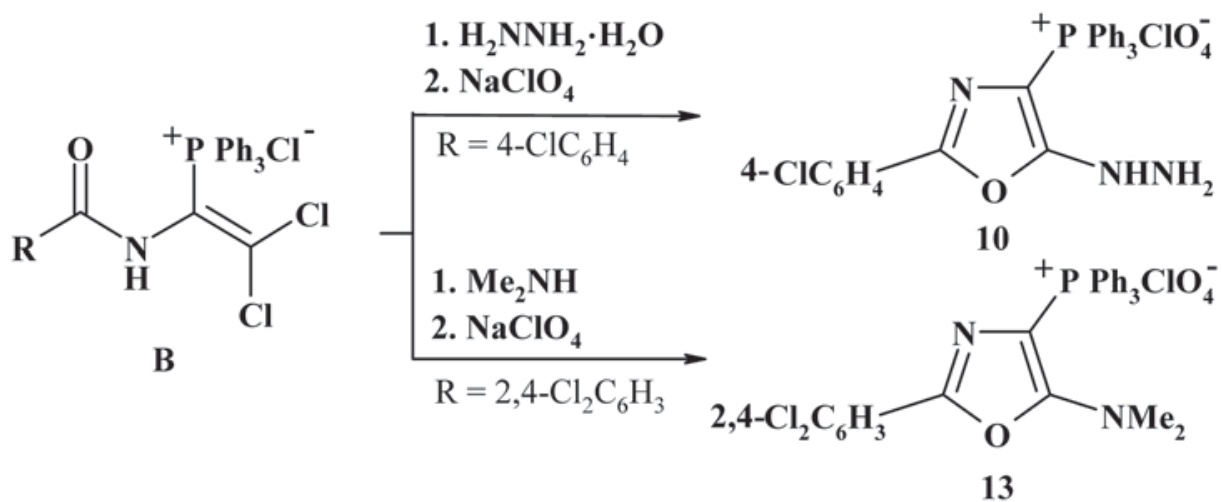

Scheme 2. Synthesis of (1,3-oxazol-4-yl)-triphenylphosphonium salts $(\mathbf{1 0}, 13)$

sis: Zorbax SB - C18 column $(1.8 \mu \mathrm{m}, 4.6 \times 15 \mathrm{~mm}$, PN 821975-932), solvent water - acetonitrile mixture (95:5), $0.1 \%$ of aqueous trifluoroacetic acid; eluent flow $3 \mathrm{ml} / \mathrm{min}$; injection volume $1 \mu \mathrm{l}$; UV detecting at 215, 254, $265 \mathrm{~nm}$; chemical ionization at atmospheric pressure (APCI), scan range m/z 80 - 1000. Elemental analysis was carried out in the Analytical Laboratory of the V.P. Kukhar Institute of Bioorganic Chemistry and Petrochemistry of the National Academy of Sciences of Ukraine by manual methods. The carbon and hydrogen contents were determined using the Pregl gravimetric method, while nitrogen was determined using the Duma's gasometrical micromethod. Sulfur was determined by the Scheininger titrimetric method, chlorine content was determined by the mercurometric method, phosphorus content was determined by the colorimetric method [40]. Uncorrected melting points were determined on a Fisher-Johns apparatus. Reactions and purity of the products were monitored by thinlayer chromatography on Silufol UV-254 plates using 9:1 (v/v) chloroform-methanol as eluent. All reagents and solvents were purchased from Aldrich and used as received. 
[2-R-4-(Triphenylphosphonium)-1,3-oxazol-5-yl] sulfanides (1-5) were synthesized following a procedure described in the literature [39].

[5-(4-Chlorophenylthio)-2-phenyl-1,3-oxazol-4-yl] triphenylphosphonium perchlorate (6) was synthesized as previously described [41].

[5-(4-Chlorophenylsulfonyl)-2-phenyl-1,3-oxazol4-yl]triphenylphosphonium perchlorate (7) was synthesized following a procedure described in the literature [42].

[2-(4-Chlorophenyl)-5-ethylthio-1,3-oxazol-4-yl] triphenylphosphonium iodide (8) was synthesized following a procedure described in the literature [43].

Colorless powder, m.p. 206-208 ${ }^{\circ} \mathrm{C}(\mathrm{EtOH})$. IR (KBr, $\left.v_{\text {max }}, \mathrm{cm}^{-1}\right): 1107,1402,1434,1474,1602$, 3048. ${ }^{1} \mathrm{H}$ NMR (400 MHz, DMSO-d ${ }_{6}$ ): $\delta 1.22$ (t, 3H, $\mathrm{J}_{\mathrm{HH}}=7.5 \mathrm{~Hz}, \mathrm{CH}_{3}$ ), 3.13 (q, 2H, J $\mathrm{HH}=7.5 \mathrm{~Hz}, \mathrm{CH}_{2}$ ), $7.68\left(\mathrm{~d}, 2 \mathrm{H}, \mathrm{J}_{\mathrm{HH}}=8.0 \mathrm{~Hz}, \mathrm{ArH}\right), 7.92-7.78(\mathrm{~m}, 12 \mathrm{H}$, ArH), 8.00-7.94 (m, 3H, ArH), $8.06\left(\mathrm{~d}, 2 \mathrm{H}, \mathrm{J}_{\mathrm{HH}}=8.0\right.$ $\mathrm{Hz}, \mathrm{ArH}) .{ }^{31} \mathrm{P}$ NMR (202 MHz, DMSO-d $\mathrm{d}_{6}$ ): $\delta 10.55$. ESI-MS, m/z: 500 [M-I] ${ }^{+}$. Found, \%: C, 55.47\%; H, 3.85\%; Cl, 5.65\%; N, 2.23\%; P, 4.93\%; S, 5.11\%. Calc. for $\mathrm{C}_{29} \mathrm{H}_{24}$ ClINOPS: C, $55.40 \%$; $\mathrm{H}, 3.85 \%$; $\mathrm{Cl}$, 5.7\%; N, 2.20\%; P, 4.80\%; S, 5.20\%.

[2-(4-Chlorophenyl)-5-(2-oxo-2-phenylethylsulphanyl)-1,3-oxazol-4-yl]triphenylphosphonium perchlorate (9) was synthesized following a procedure described in the literature [43].

[2-(4-Chlorophenyl)-5-hydrazino-1,3-oxazol-4-yl] triphenylphosphonium perchlorate (10) was synthesized following a procedure described in the literature [44].

[2-(4-Chlorophenyl)-5-chloro-1,3-oxazol-4-yl]triphenylphosphonium perchlorate (11) was synthesized as previously described [45].

[2-(2,4-Dichlorophenyl)-5-methylthio-1,3-oxazol4-yl]triphenylphosphonium iodide (12) was synthesized following a procedure described in the literature [43].

Colorless powder, m.p. $166-168{ }^{\circ} \mathrm{C}(\mathrm{EtOH})$. IR $\left(\mathrm{KBr}, v_{\max }, \mathrm{cm}^{-1}\right)$ : 691, 1107, 1432, 1467, 1589, 3043. ${ }^{1} \mathrm{H}$ NMR (400 MHz, DMSO-d $\left.{ }_{6}\right): \delta 2.64\left(\mathrm{~s}, 3 \mathrm{H}, \mathrm{CH}_{3}\right)$, $7.68\left(\mathrm{dd}, 1 \mathrm{H}, \mathrm{J}_{\mathrm{HH}}=1.5 \mathrm{~Hz}, \mathrm{~J}_{\mathrm{HH}}=6.5 \mathrm{~Hz}, \mathrm{ArH}\right), 8.02-$ $7.78(\mathrm{~m}, 16 \mathrm{H}, \mathrm{ArH}), 8.17\left(\mathrm{~d}, 1 \mathrm{H}, \mathrm{J}_{\mathrm{HH}}=8.0 \mathrm{~Hz}, \mathrm{ArH}\right)$. ${ }^{31} \mathrm{P}$ NMR (202 MHz, DMSO- $\mathrm{d}_{6}$ ): $\delta$ 10.00. ESI-MS, m/z: 520 [M-I] . Found, \%: C, 51.87\%; H, 3.26\%; Cl, 10.94\%; N, 2.16\%; P, 4.78\%; S, 4.95\%. Calc. for $\mathrm{C}_{28} \mathrm{H}_{21} \mathrm{Cl}_{2}$ INOPS: C, 51.80\%; H, 3.25\%; Cl, 10.80\%; N, 2.20\%; P, 4.75\%; S, 4.85\%.
[2-(2,4-Dichlorophenyl)-5-dimethylamino-1,3-oxazol-4-yl]triphenylphosphonium perchlorate (13). To a solution of 1-(2,4-dichlorobenzoylamino)-2,2dichloro-ethenyltriphenyl-phosphonium chloride (0.01 mol) [39] in $40 \mathrm{ml}$ of methanol, a solution of dimethylamine $(0.035 \mathrm{~mol})$ in $50 \mathrm{ml}$ methanol was added. The mixture was kept at $20-25{ }^{\circ} \mathrm{C}$ for $24 \mathrm{~h}$, and then $10 \mathrm{ml}$ of a saturated aqueous solution of sodium perchlorate was added. The formed precipitate was filtered off and recrystallized from ethanol.

Colorless powder, m.p. $226-228{ }^{\circ} \mathrm{C}$. IR ( $\mathrm{KBr}$, $\left.v_{\max }, \mathrm{cm}^{-1}\right): 1086,1102,1422,1434,1476,1624 .{ }^{1} \mathrm{H}$ NMR (400 MHz, DMSO-d $\left.\mathrm{d}_{6}\right): \delta 2.68\left(\mathrm{~s}, 6 \mathrm{H}, 2 \mathrm{CH}_{3}\right)$, $7.59\left(\mathrm{dd}, 1 \mathrm{H}, \mathrm{J}_{\mathrm{HH}}=2.0 \mathrm{~Hz}, \mathrm{~J}_{\mathrm{HH}}=6.5 \mathrm{~Hz}, \operatorname{ArH}\right)$, 7.82-7.74 (m, 7H, ArH), 7.96-7.83 (m, 10H, ArH). ${ }^{31} \mathrm{P}$ NMR (202 MHz, DMSO-d ${ }_{6}$ ): $\delta$ 14.56. ESIMS, m/z: 517 [M-ClO $]_{4}^{+}$. Found, \%: C, 67.19\%; H, 4.67\%; Cl, 13.68\%; N, 5.40\%; P, 5.97\%. Calc. for $\mathrm{C}_{29} \mathrm{H}_{24} \mathrm{Cl}_{2} \mathrm{~N}_{2} \mathrm{OP}: \mathrm{C}, 67.10 \%$; $\mathrm{H}, 4.70 \%$; Cl, $13.52 \%$; N, 5.40\%; P, 5.90\%.

Biochemistry: Determination of furin activity. $10 \mu \mathrm{l}$ of the diluted furin solution containing 0.25 unit of enzymatic activity were incubated for $1 \mathrm{~h}$ at $37^{\circ} \mathrm{C}$ with Boc-Arg-Val-Arg-Arg-AMC (final concentration $75-250 \mu \mathrm{M}$ ) in a buffer $\mathrm{pH} 7.3$ with a total sample volume $150 \mu$ l. The reaction was stopped by adding $2 \mathrm{ml}$ EDTA (initial concentration $5 \mathrm{mM}$ ) and relative fluorescence was detected with PTI Quanta Master 40 spectrofluorometer (Canada) (excitation, $380 \mathrm{~nm}$; emission, $460 \mathrm{~nm}$; both band widths $2 \mathrm{~nm}$ ). The readings were recorded over $60 \mathrm{sec}$.

Michaels-Menten constant values were determined using Lineweaver-Burk plots from three independent experiments.

Determination of inhibitory effects of the studied compounds. To prepare a stock solution (concentration $7.5 \mathrm{mM}$ ), a sample of the corresponding phosphonium salt was dissolved in DMSO. The stock solution was then diluted to the concentration required to inhibit furin. The enzyme solution ( 0.25 unit of activity), a buffer $\mathrm{pH} 7.3$ and the studied inhibitor solution were incubated at room temperature for $30 \mathrm{~min}$. Then a solution of the fluorogenic substrate was added to reach the final concentration of $100 \mu \mathrm{M}$ and enzymatic reaction was run for $1 \mathrm{~h}$ at $37^{\circ} \mathrm{C}$. The total volume of the mixture was $150 \mu \mathrm{l}$.

The reaction was terminated by adding $2 \mathrm{ml}$ EDTA solution and the quantity of the released AMC was measured as described above. Enzyme activity in the absence of the studied compounds was 
assumed to be $100 \%$. Inhibition constants $K_{\mathrm{i}}$ were determined from the Lineweaver-Burk plots.

Data analysis and plotting were carried out using Origin Professional 8.0 software (OriginLab). At least two measurements were used for each point. The experimental error did not exceed $10 \%$ of the measured value.

\section{Results and Discussion}

The structure of the synthesized triphenylphosphonium derivatives of 1,3-oxazole corresponds to the results of elemental analysis and the data of NMR and IR spectroscopy.

The inhibitory activity of phosphonium salts (Table 1) varies in the experimental conditions from $15 \%$ (compound 1) to $95 \%$ (compound 12) and depends on the chemical nature of the substituents at the C2- and C5-positions of the oxazole cycle. For example, replacement of the hydrogen atom in C2Me of oxazole 1 with a hydrophobic phenyl group (compound 2) causes an increase in the inhibitory effect almost fourfold (compound $\mathbf{2}$ inactivates furin by $55 \%)$. The introduction of $\mathrm{Ph}$ directly into the C2-position (compound 3) causes an even greater increase in inhibitory activity (84\% of enzyme inactivation). The antifurin activity of betaine 4 , which contains at C2-position a hydrophobic electronwithdrawing 4-chlorophenyl group, increases to $91 \%$. But the presence of a second chlorine atom in this benzene ring (compound 5) does not increase the degree of furin inactivation (87\% inhibition). Alkylation of the sulfur atom (compound 3) by 4-chlorophenyl group causes a drop in the activity of the compound $\mathbf{6}$, which inactivates the enzyme by only 34\%. Oxidation of the thiol group of oxazole 6 to a sulfo-group (compound 7), which is able to give additional hydrogen bonds with furin, increases the inhibitory effect (inactivation by $\sim 57 \%$ ), which, however, does not reach the level of the phosphonium salt 3 . The alkylation of the sulfur atom of the betaine 4 by an electron-donating Et-group leads to a slight decrease in the inhibitory effect: compound 8 inhibits furin by 85\%. An even greater decrease of antifurin activity is observed for the compound 9. Despite the fact that C5-substituent of oxazole 9 contains an oxygen atom, which is capable of forming an additional hydrogen bond and $\mathrm{Ph}$ can realize additional hydrophobic contacts with furin, the enzyme is inactivated only by $73 \%$. Replacement of the EtS-group presenting at the C5-position (com- pound 8) with hydrazine moiety (compound 10) does not affect practically the activity of furin, while the introduction of a chlorine atom in this position (compound 11) reduces the inhibitory effect (inactivation by $\sim 57 \%$ ). The presence of 2,4-dichlorophenyl moiety in C2 and MeS-group in the C5-position of oxazole (compound 12) causes the highest degree of furin inactivation (95\%.) However, the replacement of the MeS-group at the C5-position of the phosphonium salt 12 by $\mathrm{Me}_{2} \mathrm{~N}$ - leads to a decrease in antifurin activity (inactivation by $\sim 71 \%$ ), which is apparently due to spatial difficulties.

For a number of active compounds, the values of inhibition constants $\left(K_{\mathrm{i}}\right)$ were calculated from the graphs of Lineweaver-Burk and they are presented in Table 2. These data indicate that the most active inhibitors $\left(K_{\mathrm{i}}=1.57-1.64 \mu \mathrm{M}\right)$ are phosphonium salts containing electron-withdrawing substituents in the C2-position of oxazole (4-chlorophenyl- or 2,4-dichlorophenyl-), and at C5-position have donor groups $\left(\mathrm{CH}_{3} \mathrm{~S}-\right.$ or $\left.\mathrm{H}_{2} \mathrm{~N}-\mathrm{NH}-\right)$. It is seen that the most active compound $\mathbf{1 2}$ is a competitive inhibitor of furin. Since the positively charged triphenylphosphonium group is very bulky, it is unlikely that it can fit in the pocket of the furin active center. It can be speculated that a flat uncharged 2,4-dichlorophenyl group accommodates into this pocket and that is what causes competitive inactivation of the enzyme.

Betaine $\mathbf{4}$ interacts with furin by the mechanism of non-competitive inhibition. Triphenylphosphonium salts containing at $\mathrm{C} 2 \mathrm{p}$-chlorophenylgroup, and in the $\mathrm{C} 5$ position having an electron donating group (EtS- or $\mathrm{H}_{2} \mathrm{~N}-\mathrm{NH}$-) inactivate furin by the mechanism of mixed inhibition. (Table 2).

Fig. 1 shows examples of the corresponding graphs of Lineweaver-Burk plots, which allow determining the mechanism of furin inhibition.

Thus, as a result of the work, novel triphenylphosphonium derivatives of 1,3-oxazole were synthesized. They were found to be a new class of nonpeptide inhibitors of furin which retard the enzyme at the micromolar level. Depending on the chemical structure, they inactivate furin by the mechanism of competitive, non-competitive or mixed inhibition.

Conflict of interest. Authors have completed the Unified Conflicts of Interest form at http:// ukrbiochemjournal.org/wp-content/uploads/2018/12/ coi_disclosure.pdf and declare no conflict of interest. 
ISSN 2409-4943. Ukr. Biochem. J., 2019, Vol. 91, N 4

Ta b le 1. Screening of triphenylphosphonium derivatives of 1,3-oxazole as furin inhibitors

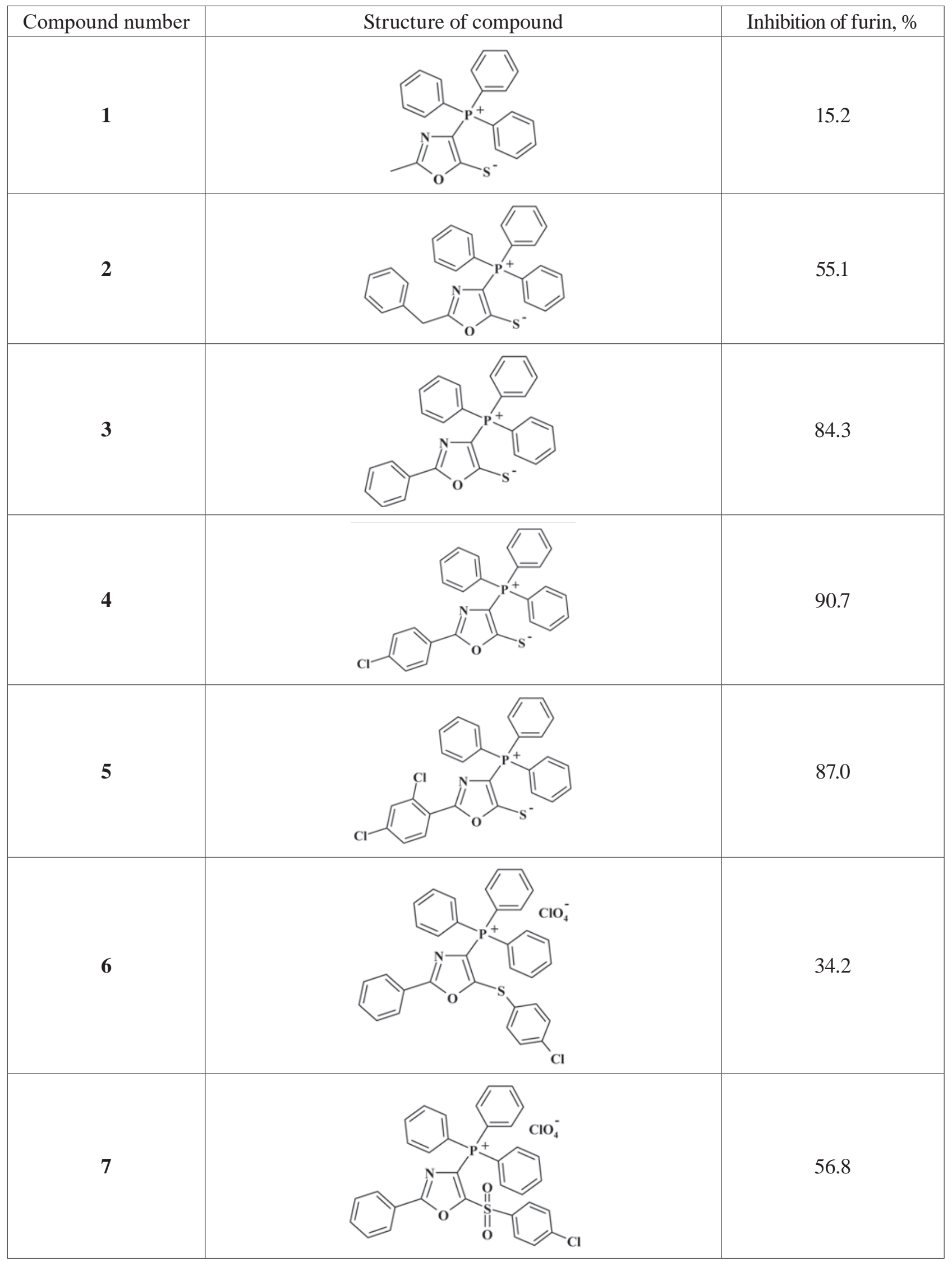

10 
Table 1. Continue

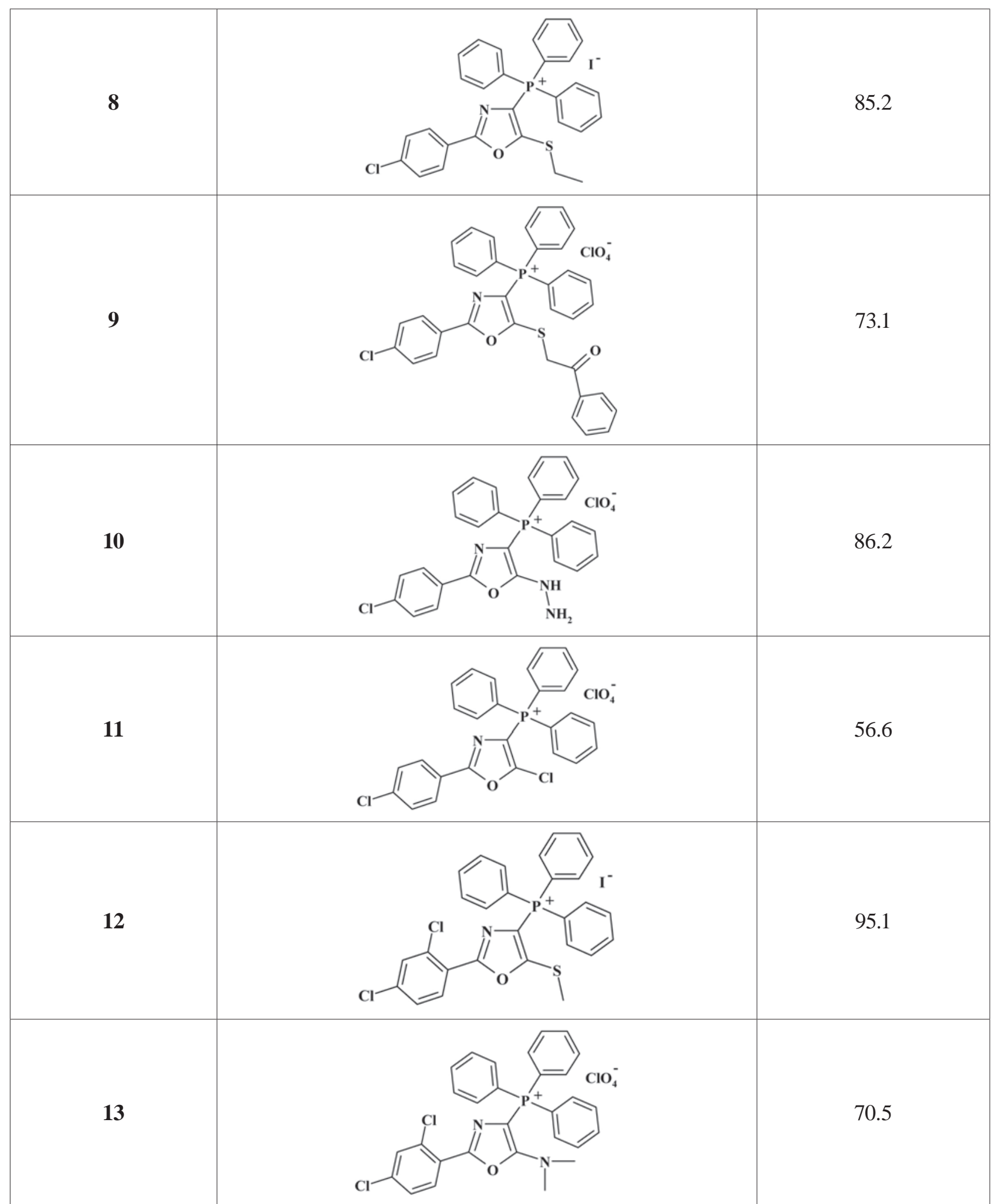

*Screening conditions: The concentration of the fluorogenic substrate was $100 \mu \mathrm{M}$ and the inhibitor under study was $500 \mu \mathrm{M}$; the total volume of the incubation medium was $150 \mu \mathrm{l}$, the sample contained 0.25 units of furin activity; the reaction was carried out for 1 hour at $\mathrm{pH}=7.3$ and $37^{\circ} \mathrm{C}$ 
Ta ble 2. Structure and properties of triphenylphosphonium derivatives of 1,3-oxazole as furin inhibitors

\begin{tabular}{|c|c|c|c|}
\hline Number & Structure of compound & $\begin{array}{l}K_{\mathrm{i}} \\
\mu \mathrm{M}\end{array}$ & Mechanism of inhibition \\
\hline 4 & & 2.25 & Non-competitive \\
\hline 8 & & 3.04 & Mixed inhibition \\
\hline 10 & & 1.64 & Mixed inhibition \\
\hline 12 & & 1.57 & Competitive \\
\hline
\end{tabular}

\section{1,3-ОКСАЗОЛ-4-ІЛФОСФОНІЄВІ СОЛІ ЯК НОВИЙ КЛАС НЕПЕПТИДНИХ ІНГІБІТОРІВ ФУРИНУ}

T. В. Осадчук ${ }^{1}$, В. К. Кібірєв ${ }^{1,2}$,

О. В. Шибирин ${ }^{1}$, А. В. Семироз ${ }^{1}$,

С. С. Велігіна ${ }^{1}$, Е. Р. Абдурахманова

B. С. Бровареив ${ }^{1}$

${ }^{1}$ Інститут біоорганічної хімії та нафтохімії ім. В. П. Кухаря НАН України, Київ; e-mail: brovarets@bpci.kiev.ua;

${ }^{2}$ Інститут біохімії ім. О. В. Палладіна НАН України, Київ

Синтезовано низку нових похідних 1,3-оксазол-4-ілфосфонієвих солей, які містять у С2- та С5-положеннях гетероциклу електронодонорні або електроноакцепторні групи. Сполуки охарактеризовано ${ }^{1} \mathrm{H},{ }^{31} \mathrm{P}$ ЯМР- та ІЧспектроскопією, даними елементного аналізу та хромато-масспектрометрії. Знайдено, що ці азоли є новим класом непептидних інгібіторів фурину. Залежно від хімічної будови вони інактивують ензим за механізмом конкурентного, неконкурентного або змішаного інгібування. Оцінка синтезованих похідних як інгібіторів фурину показала, що серед трифенілфосфонієвих солей оксазол 12, який містить у С2-положенні 2,4-дихлорфеніл-, а у C5 - MeS-групу, є найактивнішим $\left(K_{\mathrm{i}}=1,57\right.$ мкM) конкурентним інгібітором ензиму. Результати свідчать про те, що хімічна модифікація фосфонієвих похідних 

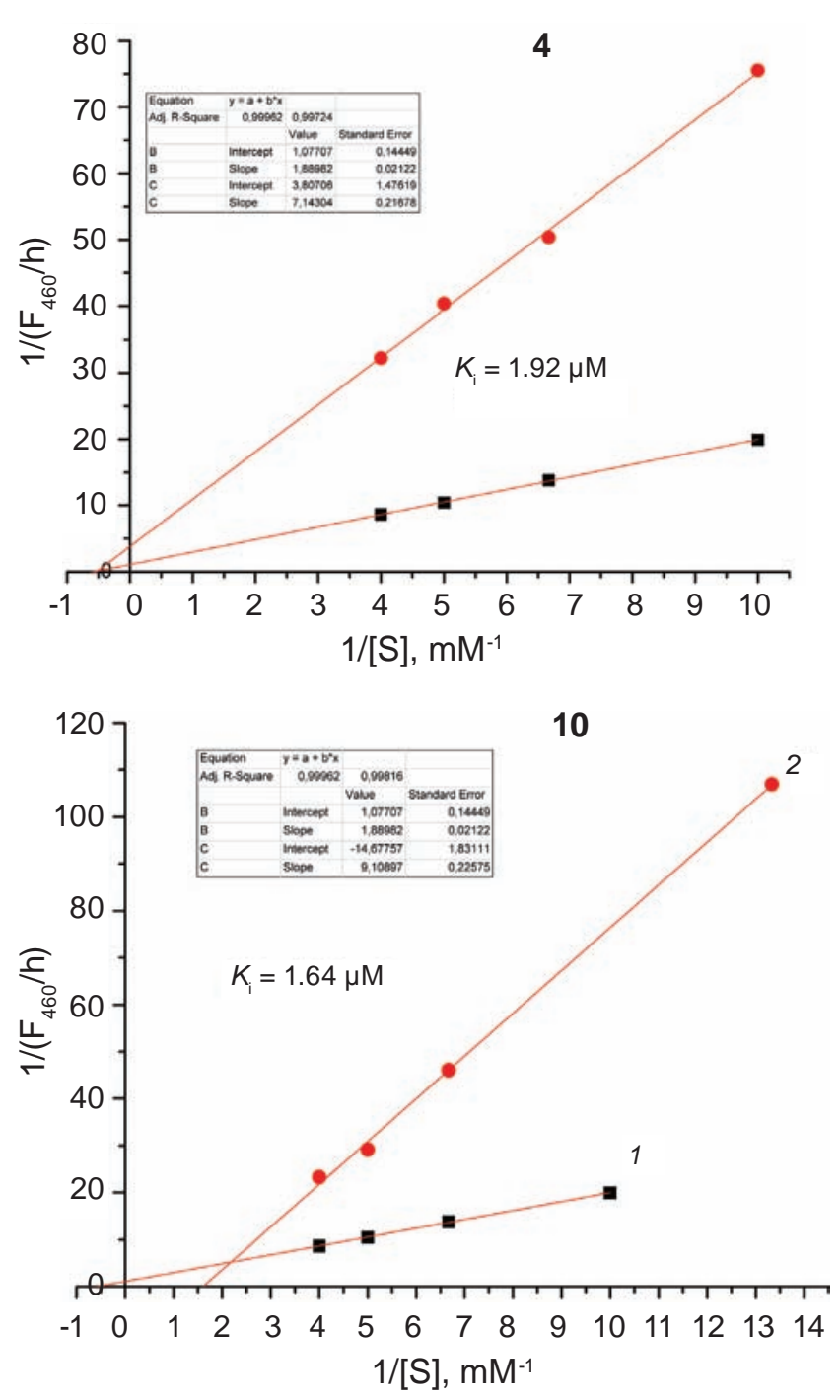

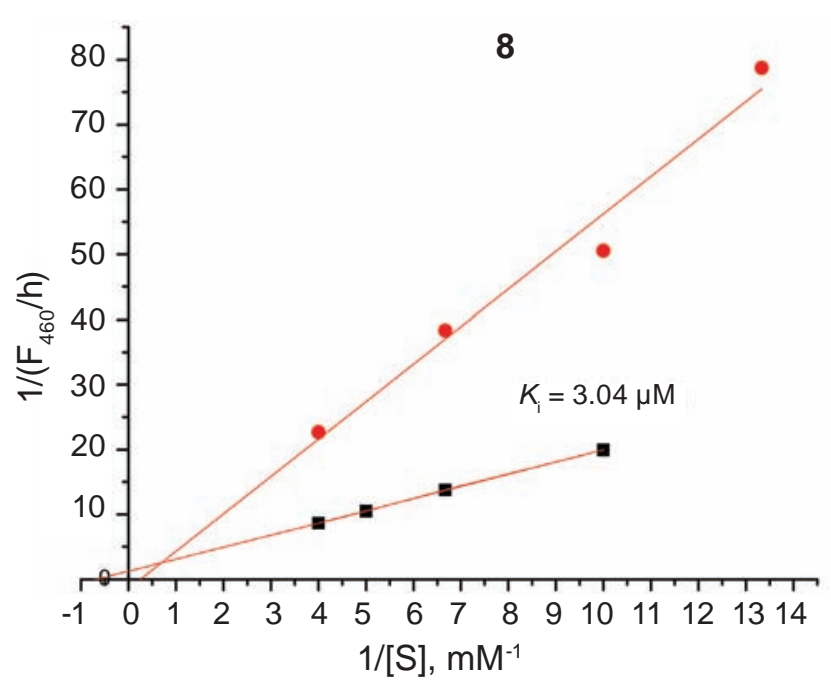

12

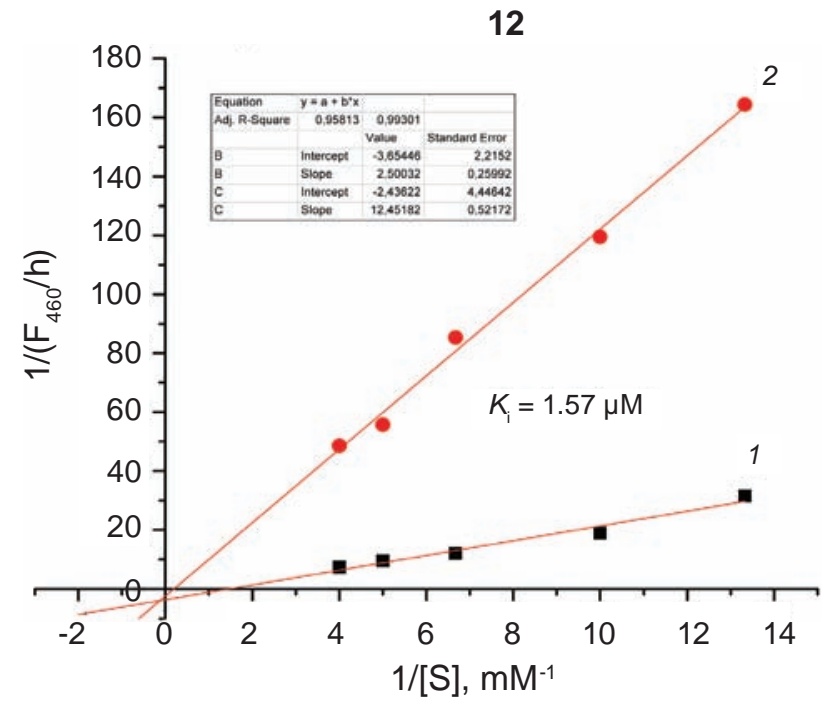

Fig. 1. Competitive, non-competitive and mixed inhibition of furin by triphenylphosphonium derivatives of 1,3-oxazole

оксазолу може бути корисною для створення потужніших та селективних інгібіторів фурину.

К л ю ч о в і с ло в а: фурин, інгібітори, похідні 1,3-оксазолу, трифенілфосфонієві солі, механізм інгібування.

\section{References}

1. Molloy SS, Bresnahan PA, Leppla SH, Klimpel KR, Thomas G. Human furin is a calcium-dependent serine endoprotease that recognizes the sequence Arg-X-X-Arg and efficiently cleaves anthrax toxin protective antigen. J Biol Chem. 1992; 267(23): 1639616402.
2. Hosaka M, Nagahama M, Kim WS, Watanabe T, Hatsuzawa K, Ikemizu J, Murakami K, Nakayama K. Arg-X-Lys/Arg-Arg motif as a signal for precursor cleavage catalyzed by furin within the constitutive secretory pathway. J Biol Chem. 1991; 66(19): 12127-12130.

3. Thomas G. Furin at the cutting edge: from protein traffic to embryogenesis and disease. Nat Rev Mol Cell Biol. 2002; 3(10): 753-766.

4. Artenstein AW, Opal SM. Proprotein convertases in health and disease. $N$ Engl J Med. 2011; 365(26): 2507-2518.

5. Seidah NG, Prat A. The biology and therapeutic targeting of the proprotein convertases. Nat Rev Drug Discov. 2012; 11(5): 367-383. 
6. Couture F, Kwiatkowska A, Dory YL, Day R. Therapeutic uses of furin and its inhibitors: a patent review. Expert Opin Ther Pat. 2015; 25(4): 379-396.

7. Basak A. Inhibitors of proprotein convertases. J Mol Med (Berl). 2005; 83(11): 844-855.

8. De UC, Mishra P, Pal PR, Dinda B, Basak A. Non-peptide inhibitors of proprotein convertase subtilisin kexins (PCSKs): An overall review of existing and new data. (ed. M. Khatib). Colloquium Series on Protein Activation and Cancer. 2012; 1(3): 1-76.

9. Kibirev VK, Osadchuk TV, Kozachenko OP, Kholodovych V, Fedoryak OD, Brovarets VS. Synthesis, biological evaluation and docking of novel bisamidinohydrazones as non-peptide inhibitors of furin. Ukr Biochem J. 2015; 87(1): 55-63.

10. Osadchuk TV, Shybyryn OV, Kibirev VK. Chemical structure and properties of lowmolecular furin inhibitors. Ukr Biochem J. 2016; 88(6): 5-25.

11. Kibirev VK, Osadchuk TV, Vadziuk OB, Shablykin OV, Kozachenko AP, Chumachenko SA, Popil'nichenko SV, Brovarets VS. Study on derivatives of 5-amino-4-acylamino-1Hpyrazole as inhibitors of furin. Ukr Biokhim Zhurn. 2011; 83(1): 30-37. (In Russian).

12. Zhang HZ, Zhao ZL, Zhou CH. Recent advance in oxazole-based medicinal chemistry. Eur $J$ Med Chem. 2018; 144: 444-492.

13. Jin Z. Muscarine, imidazole, oxazole and thiazole alkaloids. Nat Prod Rep. 2016; 33(11): 1268-1317.

14. Joshi S, Bisht AS, Juyal D. Systematic scientific study of 1,3-oxazole derivatives as a useful lead for pharmaceuticals: A review. The Pharma Innov J. 2017; 6(1): 109-117.

15. Ghani A, Hussain EA, Sadiq Z, Naz N. Advanced synthetic and pharmacological aspects of 1,3-oxazoles and benzoxazoles. Indian J Chem. 2016; 55B(7): 833-853.

16. Kachaeva MV, Pilyo SG, Zhirnov VV, Brovarets VS. Synthesis, characterization, and in vitro anticancer evaluation of 2-substituted 5-arylsulfonyl-1,3-oxazole-4-carbonitriles. Med Chem Res. 2019; 28(1): 71-80.
17. Maekawa T, Sakai N, Tawada H, Murase K, Hazama M, Sugiyama Y, Momose Y. Synthesis and biological activity of novel 5-(omegaaryloxyalkyl)oxazole derivatives as brainderived neurotrophic factor inducers. Chem Pharm Bull (Tokyo). 2003; 51(5): 565-573.

18. Zhou H, Cheng JQ, Wang ZS, Chen FH, Liu XH. Oxazole: A Promising Building Block for the Development of Potent Antitumor Agents. Curr Top Med Chem. 2016; 16(30): 3582-3589.

19. Kachaeva MV, Pilyo SG, Demydchuk BA, Prokopenko VM, Zhirnov VV, Brovarets VS. 4-Cyano-1,3-oxazole-5-sulfonamides as novel promising anticancer lead compounds. Int $J$ Curr Res. 2018; 10(5): 69410-69425.

20. Semenyuta I, Kovalishyn V, Tanchuk V, Pilyo S, Zyabrev V, Blagodatnyy V, Trokhimenko O, Brovarets V, Metelytsia L. 1,3-Oxazole derivatives as potential anticancer agents: Computer modeling and experimental study. Comput Biol Chem. 2016; 65: 8-15.

21. Semenyuta IV, Kovalishyn VV, Pilyo SG, Blagodatnyy VN, Trokhimenko EP, Brovarets VS, Metelitsa LA. Application of QSAR models to the search for tubulin inhibitors in a series of derivatives of 1,3-oxazole. Rep Nat Acad Sci Ukraine. 2014; (12): 152-157. (In Russian).

22. Song $\mathrm{MX}$, Rao $\mathrm{BQ}$, Cheng $\mathrm{BB}$, $\mathrm{Yi} \mathrm{Wu}$, Zeng H, Luo Y, Deng XQ. Design, synthesis and evaluation of the antidepressant and anticonvulsant activities of thiazole-containing benzo[d]oxazoles. CNS Neurol Disord Drug Targets. 2017; 16(2): 187-198.

23. Tomi IHR, Tomma JH, Al-Daraji AHR, AlDujaili AH. Synthesis, characterization and comparative study the microbial activity of some heterocyclic compounds containing oxazole and benzothiazole moieties. J Saudi Chem Soc. 2015; 19(4): 392-398.

24. Swellmeen L. 1,3-Oxazole derivatives: A review of biological activities as antipathogenic. Der Pharma Chemica. 2016; 8(13): 269-286.

25. Sadek B, Fahelelbom KM. Synthesis, characterization, and antimicrobial evaluation of oxadiazole congeners. Molecules. 2011; 16(6): 4339-4347. 
26. Kachaeva MV, Pilyo SG, Kornienko AM, Prokopenko VM, Zhirnov VV, Prichard MN, Keith KA, Yang G, Wang HK, Banerjee NS, Chow LT, Broker TR, Brovarets VS. In vitro activity of novel 1,3-oxazole derivatives against of human papillomavirus. Ibnosina $\mathrm{J}$ Med Biomed Sci. 2017; 9(4): 111-118.

27. Kovalishyn V, Kopernyk I, Chumachenko S, Shablykin O, Kondratyuk K, Pil'o S, Prokopenko V, Brovarets V, Metelytsia L. QSAR Studies, Design, Synthesis and Antimicrobial Evaluation of Azole Derivatives. Comput Biol Bioinform. 2014; 2(2): 25-32.

28. Kopernik IM, Blagodatnyj VM, Petrenko OV, Kalashnikova LE, Prokopenko VV, Kondratyuk KM, Lukashuk OI, Golovchenko OV, Chumachenko SA, Shablykin OV, Metelitsa LO, Brovarets VS. Study in vitro for antimicrobic activity of new oxazole derivatives and products of its transformations. Ukrainica Bioorg Acta. 2011; 9(2): 57-68. (In Ukrainian).

29. Kumar A, Ahmad P, Maurya RA, Singh AB, Srivastava AK. Novel 2-aryl-naphtho[1,2-d] oxazole derivatives as potential PTP-1B inhibitors showing antihyperglycemic activities. Eur J Med Chem. 2009; 44(1): 109-116.

30. Selva M, Perosa A, Noè M. Phosphonium salts and P-ylides. Organophosphorus Chem. 2016; 45: 132-169.

31. Trnka J, Elkalaf M, Anděl M. Lipophilic triphenylphosphonium cations inhibit mitochondrial electron transport chain and induce mitochondrial proton leak. PLoS One. 2015; 10(4): e0121837.

32. Zielonka J, Joseph J, Sikora A, Hardy M, Ouari O, Vasquez-Vivar J, Cheng G, Lopez M, Kalyanaraman B. Mitochondria-targeted triphenylphosphonium-based compounds: Syntheses, mechanisms of action, and therapeutic and diagnostic application. Chem Rev. 2017; 117(15): 10043-10120.

33. Trush MM, Kovalishyn V, Ocheretniuk AD, Kalashnikova LE, Prokopenko VM, Holovchenko OV, Kobzar OL, Brovarets VS, Metelytsia LO. New 1,3-oxazolylphosphonium salts as potential biocides: QSAR study, synthesis, antibacterial activity and toxicity evaluation. Lett Drug Design Disc. 2018; 15(12): 1259-1267.

34. Xue Y, Pan Y, Xiao H, Zhao Y. Novel quaternary phosphonium-type cationic polyacrylamide and elucidation of dual-functional antibacterial/ antiviral activity. RSC Adv. 2014; 4(87): 4688746895.

35. Trush MM, Kovalishyn VV, Blagodatnyi VM, Brovarets VS, Pilyo SG, Prokopenko VM, Hodyna DM, Metelytsia LO. QSAR studies and antimicrobial potential of 1,3-thiazolylphosphonium salts. Ukr Biochem J. 2016; 88(4): 57-65.

36. Cheng G, Zielonka J, Ouari O, Lopez M, McAllister D, Boyle K, Barrios CS, Weber JJ, Johnson BD, Hardy M, Dwinell MB, Kalyanaraman B. Mitochondria-targeted analogues of metformin exhibit enhanced antiproliferative and radiosensitizing effects in pancreatic cancer cells. Cancer Res. 2016; 76(13): 3904-3915.

37. Jameson VJ, Cochemé HM, Logan A, Hanton LR, Smith RA, Murphy MP. Synthesis of triphenylphosphonium vitamin $\mathrm{E}$ derivatives as mitochondria-targeted antioxidants. Tetrahedron. 2015; 71(44): 8444-8453.

38. Millard M, Pathania D, Shabaik Y, Taheri L, Deng J, Neamati N. Preclinical evaluation of novel triphenylphosphonium salts with broadspectrum activity. PLoS One. 2010; 5(10). pii: e13131.

39. Brovarets V, Holovchenko O, Naumenko A, Vydzhak R, Abdurakhmanova E, Prostota Ya, Kachkovsky O. Electronic and spectral properties of phosphonium ylides-betaines, derivatives of 2 oxazoline-5-one with conjugated and non-conjugated substituents. Eur Chem Bull. 2017; 6(9): 380-392.

40. Klimova VA. Basic Micromethodes for the Analysis of Organic Compounds. M.: Khimya, 1975. 224 p. (In Russian).

41. Brovarets VS, Lobanov OP, Drach BS. Syntheses of 2,5-substituted azoles from (2,2-dichloro1-acylaminovinyl)triphenylphosphonium chlorides. J Gen Chem. USSR (Engl. Transl.). 1984; 15(11): 1819-1823. 
42. Golovchenko AV, Brovarets VS, Drach BS. A convenient procedure for introducing arylsulfanyl and heterylsulfanyl groups into the 5 position of the oxazole ring. Russ J Gen Chem. 2004; 74(9): 1414-1417.

43. Brovarets VS, Lobanov OP, Kisilenko AA, Kalinin VN, Drach BS. Conversions of substituted phosphinomethylenes containing 2-alkyl-(aryl)-4,5-dihydro-5-thioxo-4-oxazolylidene fragments. J Gen Chem. USSR (Engl. Transl.). 1987; 18(6): 1323-1332.
44. Brovarets VS, Vydzhak RN, Pil'o SG, Zyuz' KV, Drach BS. Synthesis and transformations of 4-phosphorylated 2-alkyl(aryl)-5-hydrazinooxazoles. Russ J Gen Chem. 2001; 71(11): 17261728.

45. Brovarets VS, Lobanov OP, Drach BS. Synthesis of 4-phosphorylated oxazoles and thiazoles. $J$ Gen Chem. USSR (Engl. Transl.). 1983; 53(3): 574-577. 